\title{
Demonstration-Based Audio-Visual Learning Media on the Topic of Temperature, Heat, and Its Displacement in Fifth Grade
}

\author{
Sang Ayu Nyoman Ningratih ${ }^{1 *}$, I Gede Astawan ${ }^{2}$, I Gede Margunayasa ${ }^{3}$ \\ 1,2,3 Prodi Pendidikan Guru Sekolah Dasar, Universitas Pendidikan Ganesha, Singaraja, Indonesia \\ e-mail: sangayunyomanningratih@gmail.com
}

\section{A R T I C L E I N F O \\ Article history: \\ Received April 10, 2021 \\ Revised April 11, 2021 \\ Accepted June 12, 2021 \\ Available online August 25, 2021}

\section{Kata Kunci:}

Audio Visual, Demonstrasi, IPA

Keywords:

Audio-visual, Demonstration,

IPA

DOI:

https://dx.doi.org/

10.23887/jet.v5i2.34441

\begin{abstract}
A B S T R A K
Proses pembelajaran daring cenderung membuat respon dari siswa menjadi kurang aktif, oleh sebab itu diperlukan media pembelajaran yang mampu berperan aktif dalam menjelaskan materi, seperti audio visual. Tujuan penelitian ini adalah untuk menghasilkan media pembelajaran audio visual berbasis demonstrasi pada topik suhu, kalor dan perpindahannya di kelas $V$ yang valid. Model yang digunakan adalah model 4D yang terdiri dari tahap pendefinisian (define), perancangan (design), pengembangan (development), dan penyebaran (disseminate). Subjek uji coba dilakukan terhadap 2 orang ahli materi, 2 orang ahli media, dan 2 orang praktisi. Data yang dikumpulkan adalah data kualitatif dan data kuantitatif. Pengumpulan data dilakukan dengan menggunakan metode kuesioner. Data dianalisis dengan menggunakan rumus mean untuk mengetahui rata-rata skor validitas media. Rata-rata skor validitas media pembelajaran audio visual berbasis demonstrasi dari segi ahli materi sebesar 3,92 dengan kualifikasi sangat baik, dari segi ahli media sebesar 3,80 dengan kualifikasi sangat baik, dan dari segi praktisi sebesar 3,87 dengan kualifikasi sangat baik. Hal ini menunjukkan bahwa media pembelajaran audio visual berbasis demonstrasi pada topik suhu, kalor dan perpindahannya di kelas $V$ dinyatakan layak untuk digunakan dalam proses pembelajaran.
\end{abstract}

\section{A B S T R A C T}

The online learning process tends to make students' responses less active. Therefore it requires learning media that can play an active role in explaining the material, such as audiovisuals. The purpose of this study was to produce valid demonstrationbased audio-visual learning media on the topic of temperature, heat, and its displacement in the fifth grade. The model used is the 4D model, which consists of defining, designing, developing, and disseminating. The subject of the trial was conducted on two material experts, two media experts, and two practitioners. The data collected are qualitative data and quantitative data. Data collection was carried out using a questionnaire method. Data were analyzed using the mean formula to determine the average media validity score. The average validity score of demonstration-based audiovisual learning media in terms of material experts is 3.92 , with very good qualifications. In terms of media experts of 3.80 with very good qualifications. In terms of practitioners, it is 3.87 with very good qualifications. It shows that the demonstration-based audio-visual learning media on temperature, heat, and its displacement in fifth grade are deemed appropriate for use in the learning process.

This is an open access article under the CC BY-SA license.

Copyright ( 2021 by Author. Published by Universitas Pendidikan Ganesha.

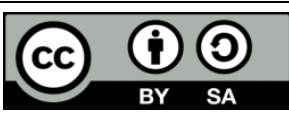

\section{INTRODUCTION}

Learning is a process of building knowledge through interactions carried out by students with teachers, fellow students, and students with their environment in a conducive atmosphere (Guevara et al., 2021; Hussin et al., 2018). The learning process should lead to a meaningful process, including the science learning process. The meaningfulness referred to in the science learning process is a learning process that can develop students' higherorder thinking skills to apply the knowledge gained in everyday life (Yulianti et al., 2016; Zulfiani et al., 2020). The ability to solve problems and think critically is part of higher-order thinking skills that must be developed in children so that later students can overcome the problems they will face (Rovers et al., 2018; Sung, 2017). Several innovations have been made to achieve student-centered learning. It is done to build their knowledge independently through the experiences they have passed (Amponsah et al., 2019; Parmin et al., 2015; Zeren Özer \& Güngör, 2017). It also applies in science learning, emphasizing providing direct experience to students to understand the natural surroundings through scientific steps. The ultimate goal is to prepare students who are responsive to their phenomena (Aini et al., 2019; Hwang et al., 2013). 
However, the reality in the field shows that the science learning process has not taken place optimally and is not yet following what was expected (Ho \& Ismawan Prasetia Devi, 2020; Suryandari et al., 2018). Several factors cause the science learning process to be not optimal. First, the learning process only focuses on completing the material, focusing on how students understand and the meaning of the material being learned (Churchill et al., 2013; Mullis et al., 2012). Second, the limited material in the science content contained in the teacher's handbook and student handbooks, and the teacher only relies on these two handbooks as learning resources (Suryawati et al., 2020; Syahroni et al., 2016). This statement results from a document study conducted on the teacher's book and student's book in fifth grade. It appears that the material presented in the book is still very limited and needs to be developed. One of them is material on the topic of temperature, heat, and its displacement. The handbook only provides a brief explanation of the material so that the limitations of the material will cause students to be confused in accepting and understanding the meaning of the material being taught. Third, the lack of innovation and teacher creativity in using and developing instructional media is also a factor. Judging from the use of instructional media, $82 \%$ of the teachers stated that they had used learning media other than books. One of them is in the form of a learning video, but the learning video used is obtained from YouTube and only contains a brief explanation of the material. The use of the learning video cannot be said to have been optimally implemented.

Meanwhile, during efforts to continue improving the quality of the learning process, especially in science, new challenges emerged by implementing online learning due to the Covid-19 pandemic (Mpungose, 2021; Yulia, 2020). Several obstacles were found in the implementation process regardless of the supporting infrastructure. The online learning process is deemed less effective in elementary schools because providing material and using learning media cannot occur optimally, and students' response tends to get bored quickly. Other obstacles to online learning students are not used to learning independently and the lack of places to ask questions about material that is not yet understood (Putria et al., 2020; Yunitasari \& Umi, 2020; Jatira \& Neviyarni, 2021). Based on the results of the PISA study released by the Organization for Economic Cooperation Development in 2018, the ability of students in the field of science in Indonesia gets a score of 389 , while the average score is 489 (Indriani, 2019). These results indicate that the science learning process that has been going on so far is still not optimal. If this problem is not resolved immediately, it will have an impact on the low learning outcomes of students. So, referring to the imbalance between the objectives of science learning with the reality of the process and results of science learning in the field, it is necessary to make an innovation in the learning implementation process by developing learning media that is relevant to the characteristics of the material and students (Anindyajati \& Choiri, 2017; Wakabayashi \& Ishikawa, 2011).

The science learning process would provide optimal results if the learning involved all the five senses of students in obtaining and building their knowledge (Atmojo et al., 2020; Subali et al., 2019). Through the involvement of all five senses, learning will become more interactive and meaningful, far from being boring. The knowledge gained can be used to deal with problems in everyday life. In realizing such learning, of course, a learning innovation is needed. Ideally, the learning process takes place using an approach, model, strategy, or learning method, and the learning media must be adapted to the characteristics of the material and students (Mohd Zain et al., 2018; Sivaramakrishnan et al., 2019). Using this learning media can provide several benefits: 1) making abstract messages more concrete, making it easier for students to understand; 2) increase the focus of students; 3) increase students 'interest and motivation so that students' learning outcomes can be improved (Komikesari et al., 2020; Ristanto et al., 2020; Saripudin et al., 2018).

The learning media developed aims to accommodate the online learning process by using demonstration-based audio-visual learning media. Audio-visual media is a medium that can be used in the learning process by relying on the sense of hearing and sense of sight (Bromberek-Dyzman et al., 2021; Xu \& $\mathrm{Wu}, 2021)$. Using audio-visual media can increase students' interest in learning because students can listen and see images simultaneously (Larue \& Watling, 2021; Pattemore \& Muñoz, 2020). Audiovisual media is a combination of audio media with visual media. Audiovisual media displaying sound (audio) and images (visual) at once in a single play which can be done through various digital applications that are used to transmit information related to learning material so that it does not only depend on word understanding (Michelsanti et al., 2019; Wang et al., 2020). So, audio-visual media can be interpreted as conveying information by combining sound and images to be understood more easily and clearly. Audiovisual media has better abilities because it includes auditive and visual media to help students acquire certain knowledge, skills, or attitudes and become a more meaningful learning experience (Michelsanti et al., 2019; Pattemore \& Muñoz, 2020). Technology that is well utilized in the learning process will optimize learning outcomes (Tuma, 2021). The audio-visual learning media is feasible to be developed because its use is practical and can improve student learning outcomes and motivation (Hanif, 2020; Sun \& Gao, 2016).

Audiovisual media will become more interesting and meaningful when combined with the right method. One method that can be used is the demonstration method. Using the demonstration method in the learning process is quite effective because it can help students find answers independently based on facts or correct data 
(Anwar \& Zulkifli, 2020; Udo, 2011). The demonstration method has a close relationship with audio-visual media when viewed from the second goal, providing a learning experience to students through viewing and listening activities. The learning process will be more memorable in students' memories because students learn through direct experience and observation. An increase in student learning outcomes by implementing demonstration methods in learning (Gumay \& Bertiana, 2018; Hernawati, 2018; Nahdi et al., 2018; Putri et al., 2017). However, the audio-visual media used in these studies have not been combined with demonstration methods. Online learning will be very effective if done with instructions and demonstrations (Tseng, 2021; Yu, 2021). At the same time, some materials, especially in science, require students to carry out a simple experiment to prove a theory or concept with reality to produce their own knowledge. So if the current learning is carried out only like what has been described above, then of course it is likely that it will cause students to feel difficult in mastering the learning material, so that in this study developing a demonstration-based audio visual media that focuses on the topic of temperature, heat and its displacement. This developed media contains material descriptions related to the topic as well as simple experiments complete with demonstration activities from each step of the experiment, so that students are able to understand and can carry out these experiments independently at home. The importance of developing this media is because demonstration-based audio-visual media can help students guide and direct students to learn independently, considering that teaching and learning activities are currently carried out online. And because of the low level of innovation and creativity of teachers in determining and using media that are relevant to the characteristics of learning faced today. Therefore, this kind of learning media is needed both by students and by the teachers themselves in the learning process, especially in learning that discusses the topic of temperature, heat and its displacement.

The use of videos in learning is the right choice because students can learn independently by watching these videos (Gabriele et al., 2016; Layona et al., 2017; Satyawan, 2018). Other research findings also state that learning videos will make it easier for students to understand learning materials (Leatherman \& Cleveland, 2020; Yildiz \& Ersan, 2011). Therefore using the demonstration method with video learning can be said to be able to increase student understanding. The purpose of developing demonstration-based audio-visual media is to produce media on the topic of temperature, heat, and their displacement in fifth-grade elementary schools whose validity has been tested so that they can be used in the field. The existence of this learning media will certainly have a positive impact, especially in science because the existence of this media can improve the quality of a learning process, develop children's interest and motivation, and improve student learning outcomes.

\section{METHOD}

This research is development research that produces a demonstration-based audio-visual learning media on temperature, heat, and displacement in fifth grade. The model used in this study is the 4D model (Define, Design, Development, and Disseminate). The steps taken in the 4D model are: 1) the implementation of the define stage is carried out by carrying out four steps of analysis, needs analysis, curriculum analysis, media analysis, and analysis of student characteristics. The needs analysis was carried out by distributing questionnaires to all fifth-grade elementary school teachers in Gugus VII, Kecamatan Buleleng, to determine the needs needed during the learning process. In curriculum analysis, it is carried out by analyzing the teacher's books and fifth-grade student books of Theme 6 on the science content to obtain core competencies and basic competencies used to determine competency achievement and learning objectives. In media analysis, it is carried out by analyzing how the criteria for good media can later be used as a guide in developing media products. The analysis of student characteristics is carried out by examining students' cognitive development theory to determine the suitability of media designs made with the characteristics of students who will use the media. 2) the design stage in this study was carried out by making a media design that was developed. It had been adjusted to the needs analysis, curriculum, media, and characteristics of students that previously analyzed into manuscripts and storyboards, 3) implementation the development stage in this research is carried out by making developed media products, which have previously been consulted with the supervisor to obtain suggestions and comments to correct existing deficiencies, and 4) disseminating the product demonstration-based audiovisual learning media using the YouTube platform. The media can be used to support the learning process.

Subjects in this development research are competent in their fields, where the experts consist of two material experts, two media experts, and two practitioners. Furthermore, the data collection method is carried out using a questionnaire method by providing a list of statements to the respondent. The statements referred to the availability of media and the problems that are often encountered in schools. At the same time, the instrument used in this study, the rating scale. The scale used on the rating scale is 1-4 (Ilhami \& Rimantho, 2017). The learning video validation sheet can be seen in Table 1, Table 2, and Table 3. 
Table 1. Material Expert Test Instruments

\begin{tabular}{cllcc}
\hline No & Aspect & \multicolumn{1}{c}{ Indicator } & Number & Total \\
\hline \multirow{3}{*}{1} & \multirow{2}{*}{ Learning } & Learning objectives & $1,2,3$ & 3 \\
& & Delivery of material & $4,5,6,7$ & 4 \\
& & Motivating quality & $8,9,10,11$ & 4 \\
2 & \multirow{2}{*}{ Material } & The relevance of the material & $12,13,14$ & 3 \\
& & Selection of materials & $15,16,17,18$ & 4 \\
\hline & & Total & & $\mathbf{1 8}$
\end{tabular}

Source: modified from (Andriawan, 2015)

Table 2. Media Expert Test Instruments

\begin{tabular}{cclcc}
\hline No & Aspect & \multicolumn{1}{c}{ Indicator } & Number & Total \\
\hline \multirow{2}{*}{1} & \multirow{2}{*}{ Media quality } & Video quality displayed & $1,2,3,4$ & 4 \\
& & Ease of use & 5,6 & 2 \\
& & Clarity of sound and text & $7,8,9,10$ & 4 \\
\multirow{2}{*}{2} & The use of & The quality of language use & $11,12,13$ & 3 \\
& language & The suitability of sentence placement & 14,15 & 2 \\
3 & \multirow{2}{*}{ Media display } & Video presentation & 16,17 & 2 \\
& & Layout & $18,19,20$ & 3 \\
\hline \multicolumn{7}{c}{ Total } & & $\mathbf{2 0}$ \\
\hline
\end{tabular}

Table 3. Practitioner Test Instruments

\begin{tabular}{|c|c|c|c|c|}
\hline No & Aspect & Indicator & Number & Total \\
\hline \multirow{3}{*}{1} & \multirow{3}{*}{ Learning } & Learning objectives & $1,2,3$ & 3 \\
\hline & & Delivery of material & $4,5,6,7$ & 4 \\
\hline & & Motivating quality & $8,9,10,11$ & 4 \\
\hline \multirow{2}{*}{2} & \multirow{2}{*}{ Material } & The relevance of the material & $12,13,14$ & 3 \\
\hline & & Material selection & $15,16,17,18$ & 4 \\
\hline \multirow{3}{*}{3} & \multirow{3}{*}{ Media quality } & Video quality displayed & $19,20,21,22$ & 4 \\
\hline & & Ease of use & 23,24 & 2 \\
\hline & & Clarity of sound and text & $25,26,27,28$ & 4 \\
\hline \multirow{2}{*}{4} & \multirow{2}{*}{$\begin{array}{l}\text { The use of } \\
\text { language }\end{array}$} & The quality of language use & $29,30,31$ & 3 \\
\hline & & The suitability of sentence placement & 32,33 & 2 \\
\hline \multirow{2}{*}{5} & \multirow{2}{*}{ Media display } & Video presentation & 34,35 & 2 \\
\hline & & Layout & $36,37,38$ & 3 \\
\hline
\end{tabular}

Source: modified from (Andriawan, 2015)

The instrument that has been compiled then carried out the validity and reliability test stages. The validity test was conducted to determine the validity level of the instrument using the Gregory formula. In contrast, the reliability test was carried out to determine the consistency or constancy of the instrument using the Percentage of Agreement formula. Based on the results of the calculation of the validity test carried out, it was found that the three instruments were at very high validity criteria. Based on the results of the calculation of the reliability test were in the very good reliability criteria.

After the data was collected using these instruments, the data analysis was then carried out using qualitative descriptive analysis techniques and quantitative descriptive analysis. Qualitative data is data obtained at the expert review stage in the form of suggestions and comments. Based on the data obtained, improvements are made to the media developed following the suggestions and comments given to better media. While quantitative data is data obtained at the expert review stage in the form of a score on the assessment sheet, then the data is calculated on average using the mean formula to obtain the validity results of the media being developed. After the average is obtained, it is then converted to a five-scale achievement level conversion table. 


\section{RESULT AND DISCUSSION}

\section{Result}

\section{The Results of The Definition Stage}

The defining stage in this study was carried out with four steps of analysis: 1) needs analysis, 2) curriculum analysis, 3) media analysis, and 4) analysis of the characteristics of students. In this study, a needs analysis was carried out by distributing questionnaires to all fifth-grade elementary school teachers in Gugus VII, Kecamatan Buleleng, to find out the needs needed during the learning process. After the distribution of the questionnaire was carried out, the results were that there was a need for a learning media that teachers in classroom learning activities could use. In curriculum analysis, it is carried out by analyzing the teacher's books and fifth-grade student books of Theme 6 on Natural Science content to obtain core competencies and basic competencies. After knowing the core competencies and basic competencies, it is continued by compiling indicators of competency achievement and learning objectives to be achieved. The core competencies are obtained based on the analysis that has been carried out. Understanding factual, conceptual, procedural, and metacognitive knowledge at the basic level by observing, questioning, and trying based on curiosity about himself, God's creatures, and their activities, as well as objects found at home, at school, and in play.

Furthermore, the basic competencies obtained from the teacher's book are applying the concept of heat transfer in everyday life. Then, the competency achievement indicators that have been compiled according to basic competencies: (1) conducting experiments on heat transfer by conduction, convection, and radiation, (2) determining the ways of heat transfer, (3) finding the difference between temperature and heat, and (4) found five daily activities that use heat energy. And, based on the indicators of competency attainment that have been compiled, then four learning objectives are to be achieved: (1) by listening to the learning videos, students can conduct experiments on heat transfer by conduction, convection, and radiation correctly, (2) by listening to it. Students can determine how to transfer heat correctly in instructional videos (3) by listening to the learning videos. Students can find the difference between temperature and heat correctly, and (4) by listening to the learning videos. Students can find five daily activities which use heat energy properly.

Furthermore, the media analysis is carried out to determine the criteria for good media that can guide developing demonstration-based audiovisual learning media. Based on the analysis that has been done, it is found that good media can be seen in terms of effectiveness, efficiency, and media communication. Meanwhile, the analysis of the characteristics of students was carried out by examining the theory of cognitive development to determine the suitability of the design of demonstration-based audiovisual learning media developed with the characteristics of students. Based on the analysis done, it was found that students at the primary school level are stated to be at the concrete operational stage, where students tend to have a concrete/real level of thinking.

\section{The Results of The Design Stage}

Based on the analysis that has been done, the implementation at the design stage is carried out by compiling media assessment instruments and designing the development of demonstration-based audiovisual learning media. The media assessment instrument produced at the design stage consisted of three instruments: (1) a validation instrument for material experts consisting of 20 statements, (2) a validation instrument for media experts consisting of 18 statement items, and (3) the validation instrument for practitioners consists of 38 statement items. The validity and reliability of the three media assessment instruments have been tested by analyzing the obtained judge test results. Based on the Gregory formula's calculation results, the three instruments are at very high content validity criteria. According to the calculations using the Percentage of Agreement formula, the reliability test results of the three instruments are also in the very good reliability criteria.

Meanwhile, based on the design made, this media is intended for fifth-grade elementary school students. The software used in making the media is Kine Master with a video duration of 11 minutes 46 seconds. The learning media is designed to have a resolution of 1080p, with a 16:9 ratio. There are two types of background music used in the video, fun music and soft music, so that the learning media becomes more interesting. There are two talents in this learning media with a classroom background image behind the talent. Furthermore, the design of the media concept is made into a storyboard form. The design of the initial concept of the product can be seen visually in Figure 1 and Figure 2. 


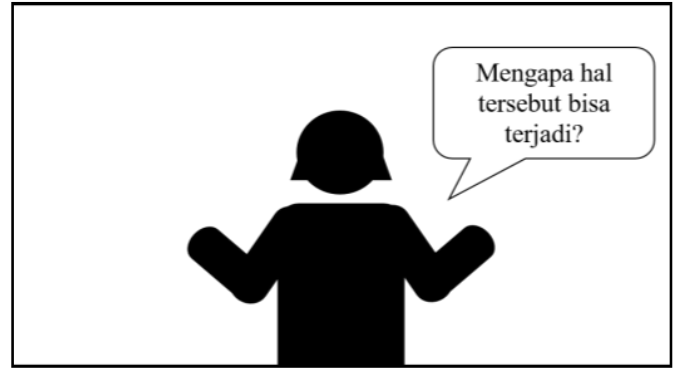

Figure 1. Storyboard Display in Giving Problems to Students

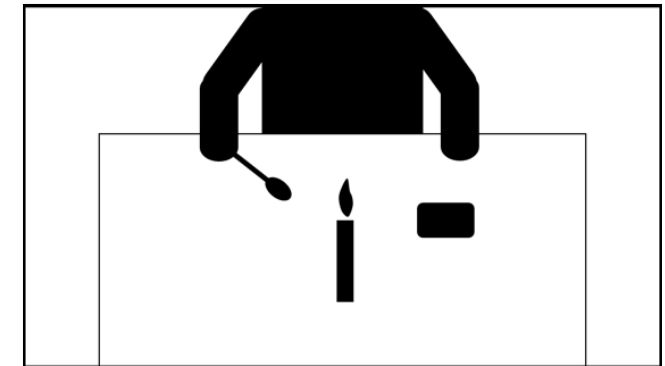

Figure 2. Storyboard Display in Giving Problems to Students

\section{The Results of The Development Stage}

The implementation of the development stage in this study was carried out by developing real media products following the script and storyboard that had been made. Furthermore, experts and practitioners' assessment is carried out to determine the validity of the media developed and to obtain suggestions and comments to improve the media to become suitable media for use in the learning process. There are some suggestions and comments given by experts, from material experts, stating that the formulation of learning objectives in media products is not following the order of levels of knowledge competency attainment in the operational verb guidelines. It is necessary to adjust the sequence. Meanwhile, media experts stated that the duration in delivery learning objectives is too fast. The duration in that section needs to be extended. It is recommended to add work relatives and thanks to the parties who contributed to the product. The text spacing needs to be adjusted so that it does not cross the video's bottom line.

The validity test of demonstration-based audio-visual learning media is carried out by providing assessment sheets to material experts, media experts, and practitioners. The data obtained on the assessment sheet then analyzed to determine the validity of the media being developed. Data analysis was carried out by calculating the average score obtained from experts and practitioners. Furthermore, the average score results are converted to the five scale conversion guidelines to determine the validity qualifications of the developed demonstration-based audiovisual learning media. The average score of validity in terms of material experts was 3.92 with very good qualifications following the five scale conversion guidelines. Then based on the data in Table 5, the average score of validity in terms of media experts was 3.80 with very good qualifications following the five scale conversion guidelines. Furthermore, based on the data in Table 6, the average validity score in terms of practitioners as a whole was 3.87 with very good qualifications according to the five scale conversion guidelines. It showed that the demonstration-based audio-visual learning media on temperature, heat, and its displacement in the fifth grade of elementary schools developed are valid. It can be stated that the learning media is suitable for use by fifth-grade elementary school teachers and students. The final product appearance after repairs based on suggestions and comments given by experts can be seen in Figure 3 and Figure 4.

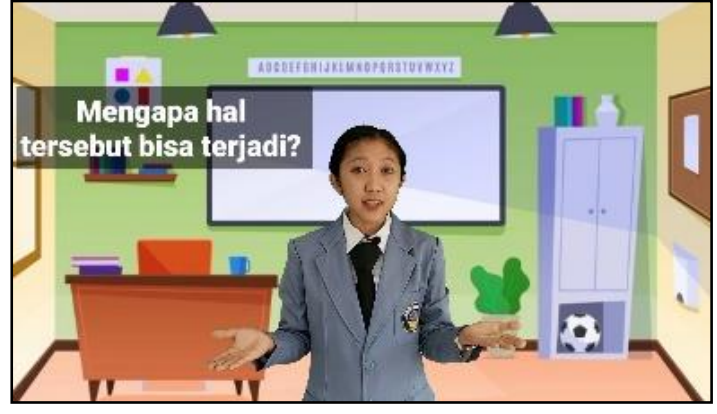

Figure 3. The Final Product Display in Giving Problems to Students

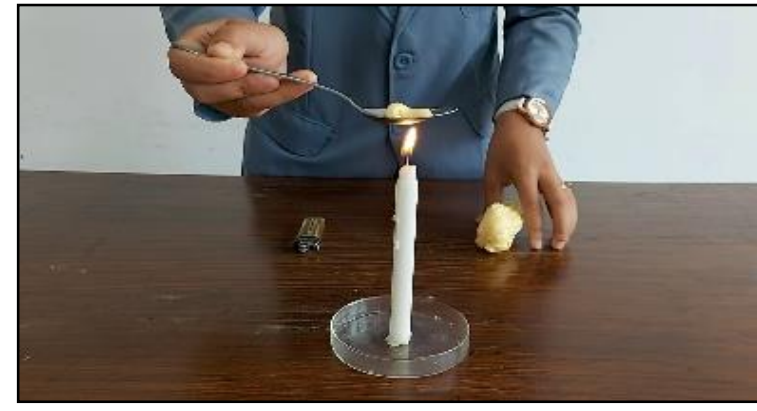

Figure 4. The Final Product Display in The Demonstration Activity

\section{The Results of The Disseminate Stage}

The implementation results at the dissemination stage, the learning media, have been distributed on the YouTube platform. Teachers and students can use demonstration-based audiovisual learning media to support the learning process. Its distribution shows that this learning media has been watched 208 times with 67 likes given. In addition, the audience also gave several comments on the uploaded audio-visual media. The material presented was easy to understand in a good manner. The content was interesting, educational, and this media 
helped students carry out learning carried out online. The audience's enthusiasm for the uploaded media can be seen, so it can be stated that the general public can accept the media.

\section{Discussion}

The learning media can be said to be good if the media is effectively and efficiently used in the learning process and the media is communicative so that in the learning process, two-way communication is created between the teacher and students (Daniels \& Gierl, 2017; Knoop-van Campen et al., 2020). In addition to meeting these three requirements, good media must also meet the five aspects of validity: (1) learning aspects consisting of learning objectives, material delivery, and motivating quality, (2) material aspects consisting of material relevance and material selection, (3) aspects of media quality consist of the quality of the video displayed, ease of use, clarity of voice and text, (4) aspects of language use consist of quality of language use, suitability of sentence placement, and (5) aspects of media display consist of video presentation and layout. The suitability of the material presented in the media will make it easier for students to learn (Emerson et al., 2020; Ran et al., 2016). In addition, the use of language that is easily understood by students will make it easier for students to absorb the information presented on the media (Heo \& Toomey, 2020; Wright et al., 2010). Furthermore, in the analysis of the characteristics of students, it was found that students at the elementary school level were declared to be at the concrete operational stage, where at this stage, students tended to have a concrete/real level of thinking (Hobri et al., 2018; Hussin et al., 2018; Sapeni \& Said, 2020). For that, we need a learning media that can provide real learning experiences to students (McNamara et al., 2020; Pradina \& Suyatna, 2018). So based on the results of the four analyses, it was found that the field needs good learning media adapted to students' material coverage and characteristics. One of the media that can be used is demonstration-based audiovisual media. Using audio-visual learning media can concretize abstract concepts, seen from students' characteristic needs, which require students at the primary school level to think concretely/real (Andriyani \& Suniasih, 2021; Bajrami \& Ismaili, 2016). So using this media can make it easier for students to understand more about the material conveyed through the media

This development research produces demonstration-based audio-visual learning media that focuses on temperature, heat, and displacement, aimed at fifth-grade elementary school students. The media developed has an attractive appearance in terms of concepts, color combinations used, clear voice, and language quality that students easily understand. An attractive media appearance will greatly influence students who use this media (Roffiq et al., 2017; Soucy et al., 2016). This display can increase students' interest, motivation, and enthusiasm to watch it, as well as in terms of design. This media also provides images that make students think in real terms, no longer abstract thinking while participating in learning. In addition, clear sound and attractive music will certainly make students feel bored quickly and provide comfort to students during the use of this media (Gabriele et al., 2016; Kawka et al., 2021). This learning media can also help teachers deliver learning material to students, especially temperature, heat, and displacement. It can be seen from the implementation of the learning process during this pandemic. The teacher has difficulties guiding students, especially experimenting, because learning was carried out remotely. So, with the existence of this media, of course, students can still carry out these simple experiments at their respective homes even without direct guidance from the teacher.

The audiovisual learning media developed have several differences from the audiovisual media that have been developed previously. The difference is that the media developed contains demonstration activities to convey material delivery more clearly. This development is carried out through a series of development stages following the 4D model procedure, defining, designing, developing, and disseminating. This development model was chosen based on the consideration that the $4 \mathrm{D}$ model is based on a constructivism approach. The learning media produced using this model can help students build their knowledge independently (Mortazavi, 2011; Teng, 2019). The reason to choose the $4 \mathrm{D}$ model is that the model has been structured so that in the development of this audio-visual learning media, it has been developed according to the stages of the model to produce a product that is suitable for use in the learning process (Arywiantari et al., 2015; Safitri et al., 2018). In addition, the difference also lies in the topic being developed, which focuses on the topic of temperature, heat, and its displacement, which have never been developed by other researchers in existing demonstration-based audiovisual learning media.

The media developed has received a positive response and can be accepted by the general public. It is reflected in media distribution on the YouTube platform, showing that this learning media has been watched 194 times with 67 likes. In addition, the audience also gave several comments regarding the uploaded audio-visual media. The material presented was easy to understand in a good manner. The content was interesting and educational, which helped students learn online (Aris et al., 2019). So it can be concluded that this media is very suitable for the learning process, especially at the elementary school level (Handayani et al., 2017). It can help students more easily accept and understand the material being learned and help teachers deliver material to students more easily. 


\section{CONCLUSION}

Demonstration-based audio-visual learning media on temperature, heat, and its displacement in fifthgrade elementary schools have very good qualifications for material experts, media experts, and practitioners. It shows that the demonstration-based audio-visual learning media on temperature, heat, and its displacement in the fifth grade of elementary schools developed are valid, so this media is suitable for use in the learning process.

\section{REFERENCES}

Aini, R. Q., Rachmatullah, A., \& Ha, M. (2019). Indonesian Primary School and Middle School Students' Attitudes toward Science: Focus on Gender and Academic Level. Journal of Baltic Science Education, 18(5), 654-667. https://doi.org/10.33225/jbse/19.18.654.

Amponsah, S., Kwesi, A. B., \& Ernest, A. (2019). Lin's Creative Pedagogy Framework As A Strategy For Fostering Creative Learning In Ghanaian Schools. Thinking Skills and Creativity, 31, 11-18. https://doi.org/10.1016/j.tsc.2018.09.002.

Andriawan, A. (2015). Pengembangan Media Pembelajaran Berbasis Video Demonstrasi pada Mata Pelajaran Praktik Batu Kelas XI Jurusan Teknik Konstruksi Batu Beton di SMKN 2 Pengasih. Jurnal Pendidikan Teknik Sipil Dan Perencanaan, 1-7. https://doi.org/http://eprints.uny.ac.id/id/eprint/21282.

Andriyani, N. L., \& Suniasih, N. W. (2021). Development of Learning Videos Based on Problem-Solving Characteristics of Animals and Their Habitats Contain in Science Subjects on 6th-Grade. Journal of Education, 5(1), 37-47. https://doi.org/10.23887/jet.v5i1.32314.

Anindyajati, Y. R., \& Choiri, A. S. (2017). The Effectiveness of Using Wordwall Media to Increase ScienceBased Vocabulary of Students with Hearing Impairment. European Journal of Special Education Research, 2(2), 1-13. https://doi.org/10.5281/zenodo.236877.

Anwar, A. I., \& Zulkifli, A. (2020). The Influence of Demonstration Method Education in the Knowledge of Tooth Brushing in Children Age 10-12 Years. Enfermería Clínica, 30(2). https://doi.org/10.1016/j.enfcli.2019.07.132.

Aris, B., Ardian, A., \& Ferry, M. (2019). Pengembangan Media Pembelajaran Berbasis E-Learning pada SMK di Pontianak. Jurnal Nasional Komputasi dan Teknologi Informasi (JNKTI), 2(2), 133. https://doi.org/10.32672/jnkti.v2i2.1556.

Arywiantari, D., Agung, A. A. G., \& Tatsra, I. D. K. (2015). Pengembangan Multimedia Interaktif Model 4D pada Pembelajaran IPA di SMP Negeri 3 Singaraja. E-Journal Edutech Undiksha, 3(1). https://doi.org/10.23887/jeu.v3i1.5611.

Atmojo, S. E., Muhtarom, T., \& Lukitoaji, B. D. (2020). The Level of Self-Regulated Learning and SelfAwareness in Science Learning in the Covid-19 Pandemic Era. Jurnal Pendidikan IPA Indonesia, 9(4), 512-520. https://doi.org/10.15294/jpii.v9i4.25544.

Bajrami, L., \& Ismaili, M. (2016). The Role of Video Materials in EFL Classrooms. Procedia - Social and Behavioral Sciences, 232(April), 502-506. https://doi.org/10.1016/j.sbspro.2016.10.068.

Bromberek-Dyzman, K., Jankowiak, K., \& Chełminiak, P. (2021). Modality Matters: Testing Bilingual Irony Comprehension in the Textual, Auditory, and Audio-Visual Modality. Journal of Pragmatics, 180. https://doi.org/10.1016/j.pragma.2021.05.007.

Churchill, D., King, M., \& Fox, B. (2013). Learning Design for Science Education in the 21st Century. Zbornik Instituta Za Pedagoska Istrazivanja, 45(2), 404-421. https://doi.org/10.2298/ZIPI1302404C.

Daniels, L. M., \& Gierl, M. J. (2017). The Impact of Immediate Test Score Reporting on University Students' Achievement Emotions in the Context of Computer-Based Multiple-Choice Exams. Learning and Instruction, 52. https://doi.org/10.1016/j.learninstruc.2017.04.001.

Emerson, A., Cloude, E. B., Azevedo, R., \& Lester, J. (2020). Multimodal Learning Analytics for Game-Based Learning. British Journal of Educational Technology, 51(5). https://doi.org/10.1111/bjet.12992.

Gabriele, K. M., Holthaus, R. M., \& Boulet, J. R. (2016). Usefulness of Video-Assisted Peer Mentor Feedback in Undergraduate Nursing Education. Clinical Simulation in Nursing, 12(8), 337-345. https://doi.org/10.1016/j.ecns.2016.03.004.

Guevara, J. L., Patel, R., \& Trivedi, J. (2021). Optimization of Steam Injection in SAGD Using Reinforcement Learning. Journal of Petroleum Science and Engineering, 4. https://doi.org/10.1016/j.petrol.2021.108735.

Gumay, O. P. U., \& Bertiana, V. (2018). Pengaruh Metode Demonstrasi terhadap Hasil Belajar Fisika Kelas X MA Almuhajirin Tugumulyo. Science and Physics Education Journal (SPEJ), 1(2), 96-102. https://doi.org/10.31539/spej.v1i2.272.

Handayani, N. M. D., Ganing, N. N., \& Suniasih, N. W. (2017). Model Pembelajaran Picture and Picture Berbantuan Media Audio-Visual terhadap Pengetahuan IPA. Journal of Education Technology, 1(3), 
176. https://doi.org/10.23887/jet.v1i3.12502.

Hanif, M. (2020). The Development and Effectiveness of Motion Graphic Animation Videos to Improve Primary School Students' Sciences Learning Outcomes. International Journal of Instruction, 13(4), 247-266. https://doi.org/10.29333/iji.2020.13416a.

Heo, M., \& Toomey, N. (2020). Learning with Multimedia: The Effects of Gender, Type of Multimedia Learning Resources, and Spatial Ability. Computers and Education, 146, 103747. https://doi.org/10.1016/j.compedu.2019.103747.

Hernawati, E. (2018). Meningkatkan Hasil Belajar Fisika melalui Penggunaan Metode Demonstrasi dan Media Audiovisual pada Siswa Kelas X MAN 4 Jakarta. Jurnal Diklat Teknis, 6(2). https://doi.org/10.36052/andragogi.v6i2.60.

Ho, L., \& Ismawan Prasetia Devi. (2020). A New Trend in Understanding Students' Interest in Learning Science: Microetnography. Integrated Science Education Journal (ISEJ), 1(2), 62-66. https://doi.org/10.37251/isej.v1i2.72.

Hobri, Septiawati, I., \& Prihandoko, A. C. (2018). High-Order Thinking Skill in Contextual Teaching and Learning of Mathematics Based on Lesson Study for Learning Community. International Journal of Engineering and Technology(UAE), 7(3), 1576-1580. https://doi.org/10.14419/ijet.v7i3.12110.

Hussin, W. N. T. W., Harun, J., \& Shukor, N. A. (2018). Problem Based Learning to Enhance Students Critical Thinking Skill via Online Tools. Asian Social Science, 15(1), 14. https://doi.org/10.5539/ass.v15n1p14.

Hwang, G. J., Yang, L. H., \& Wang, S. Y. (2013). A Concept Map-Embedded Educational Computer Game for Improving Students' Learning Performance in Natural Science Courses. Computers \& Education, 69. https://doi.org/10.1016/j.compedu.2013.07.008.

Ilhami, R. S., \& Rimantho, D. (2017). Penilaian Kinerja Karyawan dengan Metode AHP dan Rating Scale. Jurnal Optimasi Sistem Industri, 16(2), 150-157. https://doi.org/10.25077/josi.v16.n2.p150-157.2017.

Indriani. (2019). Hasil Pisa Tunjukkan Perspektif Pendidikan Indonesia. Antarnews.

Jatira, Y., \& Neviyarni S. (2021). Fenomena Stress dan Pembiasaan Belajar Daring di Masa Pandemi Covid-19. Jurnal Ilmu Pendidikan, 3(1), 35-43. https://doi.org/10.31004/edukatif.v3i1.187.

Kawka, M., MH.Gall, T., Fang, C., Liu, R., \& Jiao, R. (2021). Intraoperative Video Analysis and Machine Learning Models Will Change the Future of Surgical Training. Intelligent Surgery, 1(1). https://doi.org/10.1016/j.isurg.2021.03.001.

Knoop-van Campen, C. A. N., Segers, E., \& Verhoeven, L. (2020). Effects of Audio Support on Multimedia Learning Processes and Outcomes in Students with Dyslexia. Computers and Education, 150(February), 103858. https://doi.org/10.1016/j.compedu.2020.103858.

Komikesari, H., Mutoharoh, M., Dewi, P. S., Utami, G. N., Anggraini, W., \& Himmah, E. F. (2020). Development of E-Module Using Flip Pdf Professional on Temperature and Heat Material. Journal of Physics: Conference Series, 1572(1). https://doi.org/10.1088/1742-6596/1572/1/012017.

Larue, G. S., \& Watling, C. N. (2021). Acceptance of Visual and Audio Interventions for Distracted Pedestrians. Transportation Research Part F: Traffic Psychology and Behaviour, 76. https://doi.org/10.1016/j.trf.2020.12.001.

Layona, R., Yulianto, B., \& Turnadi, Y. (2017). Authoring Tool for Interactive Video Content for Learning Programming. Procedia Computer Science, 116, 37-44. https://doi.org/10.1016/j.procs.2017.10.006.

Leatherman, J. L., \& Cleveland, L. M. (2020). Student Exam Performance in Flipped Classroom Sections is Similar to That in Active Learning Sections, and Satisfaction with the Flipped Classroom Hinges on Attitudes Toward Learning from Videos. Journal of Biological Education, 54(3), 328-344. https://doi.org/10.1080/00219266.2019.1575266.

McNamara, J., Sweetman, S., Connors, P., Lofgren, I., \& Greene, G. (2020). Using Interactive Nutrition Modules to Increase Critical Thinking Skills in College Courses. Journal of Nutrition Education and Behavior, 5(4). https://doi.org/10.1016/j.jneb.2019.06.007.

Michelsanti, D., Tan, Z.-H., Sigurdsson, S., \& Jensen, J. (2019). Deep-Learning-Based Audio-Visual Speech Enhancement in Presence of Lombard Effect. Speech Communication, 115. https://doi.org/10.1016/j.specom.2019.10.006.

Mohd Zain, N., Mohd Fadil, N. F., \& Abdul Hadi, A. (2018). Learning Management System: An Experience and Perception Study from Medical Imaging Lecturers and Scholars in a Private University. International Journal of Interactive Mobile Technologies (IJIM), 12(7), 174. https://doi.org/10.3991/ijim.v12i7.9638.

Mortazavi, S.-M. (2011). The Relationship Between Time Lapse Between Introducing Lexical Advance Organizers and Video Viewing, and Comprehension in a Foreign Language Classroom. Procedia Social and Behavioral Sciences, 15. https://doi.org/10.1016/j.sbspro.2011.04.047.

Mpungose, C. B. (2021). Lecturers' Reflections on Use of Zoom Video Conferencing Technology for ELearning at a South African University in the Context of Corona Virus. African Identities. https://doi.org/10.1080/14725843.2021.1902268. 
Mullis, I. V., Martin, M. O., Minnich, C. A., Stanco, G. M., Arora, A., Centurino, V. A., \& Castle, C. E. (2012). TIMSS 2011 Encyclopedia: Education Policy and Curriculum in Mathematics and Science. In Pirls (Vol. 1). https://doi.org/10.6209/JORIES.2017.62(1).03.

Nahdi, D. S., Devi, A. Y., \& Nurul, F. . (2018). Upaya Meningkatkan Pemahaman Konsep Siswa melalui Penerapan Metode Demonstrasi pada Mata Pelajaran IPA. Jurnal Cakrawala Pendas, 4(2). https://doi.org/10.31949/jcp.v4i2.1050.

Parmin, Sajidan, Ashadi, \& Sutikno. (2015). Skill of Prospective Teacher in Integrating the Concept of Science with Local Wisdom Model. Jurnal Pendidikan IPA Indonesia, 4(2), 120-126. https://doi.org/10.15294/jpii.v4i2.4179.

Pattemore, A., \& Muñoz, C. (2020). Learning L2 Constructions from Captioned Audio-Visual Exposure: The Effect of Learner-Related Factors. System, 93. https://doi.org/10.1016/j.system.2020.102303.

Pradina, L. P., \& Suyatna, A. (2018). Atom Core Interactive Electronic Book to Develop Self Efficacy and Critical Thinking Skills. Turkish Online Journal of Educational Technology-TOJET, 17(1), 17-23.

Putri, A. I. K. D., Prihandono, T., Aristya, P. D., \& Putra. (2017). Penerapan Model Pembelajaran Talking Stick Disertai Metode Demonstrasi Berbantuan Media Kokami Mata Pelajaran IPA di SMP. Jurnal Pembelajaran Fisika, 5(4), 321-328. https://jurnal.unej.ac.id/index.php/JPF/article/view/4226.

Putria, H., Maula, L. H., \& Uswatun. D. A. (2020). Analisis Proses Pembelajaran Dalam Jaringan (DARING) Masa Pandemi COVID-19 pada Guru Sekolah Dasar. Jurnal Basicedu, 4(4), 861-872. https://doi.org/10.31004/basicedu.v4i4.460.

Ran, W., Yamamoto, M., \& Xu, S. (2016). Media Multitasking During Political News Consumption: A Relationship with Factual and Subjective Political Knowledge. Computers in Human Behavior, 56. https://doi.org/10.1016/j.chb.2015.12.015.

Ristanto, R. H., Rusdi, R., Mahardika, R. D., Darmawan, E., \& Ismirawati, N. (2020). Digital Flipbook Imunopedia (DFI): A Development in Immune System e-Learning Media. International Journal of Interactive Mobile Technologies (IJIM), 14(19), 140-162. https://doi.org/10.3991/ijim.v14i19.16795.

Roffiq, A., Qiram, I., \& Rubiono, G. (2017). Media Musik dan Lagu pada Proses Pembelajaran. JPDI (Jurnal Pendidikan Dasar Indonesia), 2(2), 35. https://doi.org/10.26737/jpdi.v2i2.330.

Rovers, S. F. E., Clarebout, G.Rovers, S. F. E., Clarebout, G., Savelberg, H. H. C. M., \& Merriënboer, V. (2018). Improving Student Expectations of Learning in a Problem-Based Environment. Computers in Human Behavior, 87, 416-423. https://doi.org/10.1016/j.chb.2018.02.016.

Safitri, R. W., Primiani, C. N., \& Hartini, H. (2018). Pengembangan Media Flashcard Tematik Berbasis Permainan Tradisional untuk Kelas IV Subtema Lingkungan Tempat Tinggalku. Pendidikan Dasar dan Pembelajaran, 8(1), 11. https://doi.org/10.25273/pe.v8i1.1332.

Sapeni, M. A.-A. R., \& Said, S. (2020). The Effectiveness of Case-Based Learning in Increasing Critical Thinking of Nursing Students: A Literature Review. Enfermería Clínica, 30(2). https://doi.org/10.1016/j.enfcli.2019.07.073.

Saripudin, E., Sari, I., \& Mukhtar, M. (2018). Using Macro Flash Animation Media on Motion Material to Improve Learning Achievement for Learning Science in Junior High School. , 4 (1),. Journal of Science Research and Learning, 4(1), 68-75. https://doi.org/10.30870/jppi.v4i1.3316.

Satyawan, V. (2018). The Use of Animation Video to Teach English at Junior High School Students. Jellt (Journal of English Language and Language Teaching), 2(2), 89-96. https://doi.org/10.36597/jellt.v2i2.3277.

Sivaramakrishnan, D., Fitzsimons, C., Kelly, P., Ludwig, K., Mutrie, N., Saunders, D. H., \& Baker, G. (2019). The Effects of Yoga Compared to Active and Inactive Controls on Physical Function and Health Related Quality of Life in Older Adults-Systematic Review and Meta-Analysis of Randomised Controlled Trials. International Journal of Behavioral Nutrition and Physical Activity, 16(1), 1-22. https://doi.org/10.1186/s12966-019-0789-2.

Soucy, J. N., Owens, V. A. M., Hadjistavropoulos, H. D., Dirkse, D. A., \& Dear, B. F. (2016). Educating Patients about Internet-Delivered Cognitive Behaviour Therapy: Perceptions among Treatment Seekers and Non-Treatment Seekers Before and After Viewing an Educational Video. Internet Interventions, 6 , 57-63. https://doi.org/10.1016/j.invent.2016.09.003.

Subali, B., Kumaidi, Aminah, N. S., \& Sumintono, B. (2019). Student Achievement Based on the Use of Scientific Method in the Natural Science Subject in Elementary School. Jurnal Pendidikan IPA Indonesia, 8(1), 39-51. https://doi.org/10.15294/jpii.v8i1.16010.

Sun, H., \& Gao, Y. (2016). Impact of an Active Educational Video Game on Children's Motivation, Science Knowledge, and Physical Activity. Journal of Sport and Health Science 5, 239-245. https://doi.org/10.1016/j.jshs.2014.12.004.

Sung, E. (2017). The Influence of Visualization Tendency on Problem-Solving Ability and Learning Achievement of Primary School Students in South Korea. Thinking Skills and Creativity, 26, 168-175. 
https://doi.org/10.1016/j.tsc.2017.10.

Suryandari, Sajidan, Rahardjo, Prasetyo, \& Fatimah. (2018). Project-Based Science Learning and Pre-Service Teachers' Science Literacy Skill and Creative Thinking. Cakrawala Pendidikan, 37(3). https://doi.org/10.21831/cp.v38i3.17229.

Suryawati, E., Suzanti, F., Zulfarina, Putriana, A. R., \& Febrianti, L. (2020). The Implementation of Local Environmental Problem-Based Learning Student Worksheets to Strengthen Environmental Literacy. Jurnal Pendidikan IPA Indonesia, 9(2), 169-178. https://doi.org/10.15294/jpii.v9i2.22892.

Syahroni, M. W., Dewi, N. R., \& Kasmui. (2016). The Effect of Using Digimon (Science Digital Module) with Scientific Approach at the Visualization of Students' Independence and Learning Results. Jurnal Pendidikan IPA Indonesia, 5(1), 116-122. https://doi.org/10.15294/jpii.v5i1.5800.

Teng, (Mark) Feng. (2019). The Effects of Video Caption Types and Advance Organizers on Incidental L2 Collocation Learning. Computers \& Education, 142. https://doi.org/10.1016/j.compedu.2019.103655.

Tseng, S. (2021). The Influence of Teacher Annotations on Student Learning Engagement and Video Watching Behaviors. International Journal of Educational Technology in Higher Education, 18(1), 1-17. https://doi.org/10.1186/s41239-021-00242-5.

Tuma, F. (2021). The Use of Educational Technology for Interactive Teaching in Lectures. Annals of Medicine and Surgery 62, 231-235. https://doi.org/10.1016/j.amsu.2021.01.051.

Udo, M. (2011). Effect of Guided-Discovery, Student- Centred Demonstration and the Expository Instructional Strategies on Students' Performance in Chemistry. African Research Review. https://doi.org/10.4314/afrrev.v4i4.69237.

Wakabayashi, Y., \& Ishikawa, T. (2011). Spatial Thinking in Geographic Information Science: A Review of Past Studies and Prospects for the Future. Procedia - Social and Behavioral Sciences, 21, 304-313. https://doi.org/10.1016/j.sbspro.2011.07.031.

Wang, Z., Wang, L., \& Huang, H. (2020). Joint Low Rank Embedded Multiple Features Learning for AudioVisual Emotion Recognition. Neurocomputing, 338. https://doi.org/10.1016/j.neucom.2020.01.017.

Wright, McDowell, Leese, \& McHardy, K. C. (2010). A Scoping Exercise of Work-Based Learning and Assessment in Multidisciplinary Health Care in Scotland. Journal of Practice Teaching \& Learning, 10(2). https://doi.org/10.1921/ 174661110X592737.

Xu, X., \& Wu, H. (2021). Audio-Visual Interactions Enhance Soundscape Perception in China's Protected Areas. Urban Forestry \& Urban Greening, 61. https://doi.org/10.1016/j.ufug.2021.127090.

Yildiz, S., \& Ersan, Y. (2011). A Study on PC-Video Games in Terms of the Space Awareness from Childhood to Youth. Procedia - Social and Behavioral Sciences, 28. https://doi.org/10.1016/j.sbspro.2011.11.145.

$\mathrm{Yu}, \mathrm{Z}$. (2021). The Effects of Gender, Educational Level, and Personality on Online Learning Outcomes During The Covid-19 Pandemic. International Journal of Educational Technology in Higher Education, 18(1), 1-17. https://doi.org/10.1186/s41239-021-00252-3.

Yulia. (2020). Online Learning to Prevent the Spread of Pandemic Corona Virus in Indonesia. ETERNAL (English Teaching Journal), 11(1). https://doi.org/10.26877/eternal.v11i1.6068.

Yulianti, D., Khanafiyah, S., \& Sulistyorini, S. (2016). Inquiry-Based Science Comic Physics Series Integrated with Character Education. Jurnal Pendidikan IPA Indonesia, 5(1), 38-44. https://doi.org/10.15294/jpii.v5i1.5787.

Yunitasari, R., \& Hanifah, U. (2020). Pengaruh Pembelajaran Daring terhadap Minat Belajar Siswa pada Masa Covid-19. Edukatif: Jurnal Ilmu Pendidikan, 2(3), 232-243. https://doi.org/10.31004/edukatif.v2i3.142.

Zeren Özer, D., \& Güngör, S. N. (2017). Analysis of Middle School Students' Views and Impressions about a Science Center. Journal of Turkish Science Education, 14(4), 108-125. https://doi.org/10.12973/tused.10216a.

Zulfiani, Suwarna, I. P., \& Sumantri, M. F. (2020). Science Adaptive Assessment Tool: Kolb's Learning Style Profile and Student's Higher Order Thinking Skill Level. Jurnal Pendidikan IPA Indonesia, 9(2), 194207. https://doi.org/10.15294/jpii.v9i2.23840. 